\title{
Po co taniec?
}

Anastasia Nabokina

TEKSTY DRUGIE 2020, NR 2, S. 201-214

DOI: 10.18318/td.2020.2.14 | ORCID: 0000-0001-7418-826X

Musisz kochać taniec, aby się z nim trzymać. Nie daje nic w zamian, nie pozostawia po sobiemanuskryptów, żadnych obrazów do wieszania i sprzedaży, nic, poza ta pojedyncza ulotna chwila, kiedy czujesz, że żyjesz.

Merce Cunningham ${ }^{1}$

$T$ Tak określa cel działań twórczych Gilles Deleuze: „Istnieje bowiem wspólnota sztuk, wspólny problem: w sztuce, tak w malarstwie, jak i muzyce, nie idzie o to, by reprodukować czy wymyślać formy, lecz by uchwycić siły"2. Pozostaje żałować, że filozof nie zajął się nigdy tańcem, będącym przecież kłębowiskiem sił, które czyni widocznymi. Zresztą ogólnie filozofia nie poświęciła zbyt

1 Cyt. za: M. Sheets-Johnstone Ruch - podstawa realności świata, przeł. K. Zieliński, w: Strategie choreograficzne. Nowe perspektywy, red. T. Ciesielski, M. Bartosiak, Wydawnictwo Uniwersytetu Łódzkiego, Instytut Muzyki i Tańca, Łódź-Warszawa 2017, s. 52.

2 G. Deleuze Logika wrażenia, przeł. M. Kędzierski, „Kwartalnik Artystyczny" $2005 \mathrm{nr} 4$ (48), s. 95.

\begin{abstract}
Anastasia
Nabokina - mgr, doktorantka w Katedrze Antropologii Literatury i Badań Kulturowych UJ, zajmuje się historią i teorią tańca w kontekście antropologii ciała, antropologii teatru oraz etnoscenologii. Absolwentka Moskiewskiej Akademii Choreografii, w latach 1990-2010 pierwsza solistka moskiewskiego Teatru Baletu na Kremlu oraz Teatru Wielkiego - Opery Narodowej w Warszawie. Współredaktorka numeru tematycznego pt. Pamięć gestu. Reżimy ciała w Europie Środkowej iWschodniej „Kultura Współczesna" 2018/1 oraz autorka artykułu Laboratorium ciała: Kasjan Golejzowski inowy taniec w Rosji na poczq̨tkuXX wieku. Kontakt: nabokina@ gmail.com
\end{abstract}


dużo uwagi sztuce tańca. Od czasów przewrotu kopernikańskiego Kanta najważniejszym problemem, który starała się rozwiązać, było przezwyciężenie ograniczeń poznania, a znaczenie poszczególnych sztuk rozpatrywano według ich roli w tym procesie. Mimetyczne odwzorowanie rzeczywistości nie jest cechą charakteryzującą taniec i może właśnie dlatego nie znajdował się on w centrum zainteresowań filozofii. Taniec nie wpisał się również w bardzo rozpowszechnioną klasyfikację sztuk Georga Wilhelma Friedricha Hegla, którego dynamiczny duch absolutny rozwija się w czasie na zasadzie dialektycznej, objawiając się w sztuce, religii i filozofii³. Samopoznająca ruchliwość ducha wydaje się idealnym wyrazem istoty tańca, jednak jego medium - ciało ludzkie - jest zbyt materialne i zmysłowe, by zgodnie z zasadą wyzwolenia idei z zewnętrznej zmysłowej formy taniec zajął jakieś miejsce w tej hierarchii. Dopiero „filozofujący młotem” Friedrich Nietzsche odwrócił tę gradację. Pisał:

Uczyć się myśleć - w szkołach naszych nie ma się już o tem pojęcia. [...] we wspomnieniu nawet nie marzy się o tem, iż myślenie wymaga techniki, planu naukowego, woli mistrzostwa - że myślenia trzeba się uczyć, jak trzeba się uczyć tańca [...]. Od dostojnego wychowania jest bowiem nieodłączny taniec w każdej formie, możność pląsania nogami, pojęciami, słowami: mamże jeszcze nadmieniać, iż trzeba umieć pląsać także piórem $[\ldots] ?^{4}$

Użyta przez Nietzschego metafora pląsu rozbija ideał nowoczesnego podmiotu. Wszystkiemu, co ludzkie, filozof przeciwstawił tańczącego nadczłowieka, a zwinność, lekkość, giętkość taneczną zrównał z precyzją i jasnością poznawczą. Myśl Nietzschego dokonała przewrotu w filozofii, ale także rewolucji w sztuce tanecznej. Twórcy tańca nowoczesnego - Isadora Duncan, Rudolf Laban, Mary Wigman - uwierzyli w „tańczącego boga”, przyjmując jako swoje poglądy Nietzschego. WXX wieku taniec przybiera najrozmaitsze formy, praktycy i adepci tej sztuki piszą kolejne manifesty, jednak ani w filozofii, ani w naukach o kulturze figura pląsu więcej się nie pojawia. Mimo stałego zainteresowania XX-wiecznej humanistyki cielesnością, performatywnością,

3 G. W. F. Hegel Wykłady o estetyce. Wstęp do estetyki, przeł. J. Grabowski, A. Landman, PWN, Warszawa 1964.

4 F. Nietzsche Zmierzch bożyszcz, czyli jak filozofuje się młotem, przeł. S. Wyrzykowski, Vis-à-vis/ Etiuda, Kraków 2011, s. 57. 
afektami taniec nie pojawia się jako pojęcie paradygmatyczne żadnego ze zwrotów badawczych w humanistyce. Czy to nie paradoks?

Powszechnie uważa się, że taniec jest medium uniwersalnym, przekazuje komunikat rozumiany bez słów. I taką też funkcję często pełni w filmie czy przedstawieniu teatralnym, oddając fantazje, często erotyczne, bohaterów, wyrażając ich filozofię życiową czy chwilowe nastroje. Sam jednak z trudem poddaje się opisowi. Ma cechę wyróżniającą - ruch - sprawiającą badaczom kłopoty interpretacyjne. Analiza naukowa potrzebuje pewnego dystansu, na który ruch nie pozwala. Doznania wzrokowe w tym przypadku nie wystarczają. Taniec jest immanentnie związany z ciałem, które jest tu zarówno podmiotem, jak i przedmiotem działania, a za jego odbiór odpowiada zmysł kinestezji. Ruch nie daje się rozłożyć na znaki, jest czymś więcej niż sumą gestów, a jego struktury są tak zmienne, że należałoby tu mówić o dynamice, ciaggach i przepływach energii zamiast o pozycjach, częściach ciała wykonujących ruch i elementach technicznych choreografii. W przeciwieństwie do zmysłów wzroku i słuchu, które przekazują doznania zewnętrzne wobec podmiotu, wrażenia kinestetyczne powstają w ciele i z reguły nie są uświadamiane. Jak więc badać taniec?

\section{Taniec na ścieżce neurobadań}

W swojej książce Taniec $w$ sprzężeniu nauk i technologii. Nowe perspektywy w badaniach tańca Sandra Frydrysiak proponuje, by zwrócić uwagę na poznawczy potencjał tańca. Pierwsza sugerowana ścieżka badawcza (autorka określa ją jako „miękką") dotyczy „teorii podkreślających znaczącą rolę ciała i ucieleśniania w procesach poznania"5. Badaczkę interesuje historia teoretycznego, filozoficznego zwrotu ku badaniom percepcyjnym ciała w ruchu. Z tej perspektywy jako wiedza o cielesnym poznaniu omawiana jest kinestezja ${ }^{6}$, ważne okazują się dla tańca inspiracje pochodzące z fenomenologii i filozofii egzystencjalnej', jako impuls do badań pojawiają się: psychologia rozwojowa Daniela Sterna, ekologiczne podejście do procesów percepcyjnych Jamesa Gibsona, koncepcja „myślenia w ruchu” Maxine Sheets-Johnstone oraz

5 S. Frydrysiak Taniec w sprzężeniu nauki technologii. Nowe perspektywy w badaniach tańca, Przypis, Instytut Muzyki i Tańca, Łódź-Warszawa 2017, s. 10.

6 Wiedzę o kinestezji autorka czerpie z: S.L. Foster, Choreographing Empathy. Kinestesia in Performance, Routledge, London-New York 2011.

7 Chodzi przede wszystkim o myśl Maurce'a Merleau-Ponty'ego oraz Sondry Fraleigh. 
„umysłu rozszerzonego" Andy'ego Clarka i Davida Chalmersa. Najważniejszy wniosek tej części pracy brzmi: taniec wytwarza konkretny sposób doświadczania świata przez ciało i jego zmysły, wpisuje się w rozważania nad ciałem w kulturze, może być również interpretowany jako trening poznawczy.

Pierwszy rozdział przygotowuje czytelnika do tak zwanej twardej ścieżki (autorka nazywa ją także "mocną") w badaniach nad tańcem - perspektywy neurokognitywistycznej. Z przedstawionych w drugiej części pracy argumentów wynika, że taniec jako źródło specjalistycznej wiedzy o ruchu dostarcza neurobiologom wielu inspiracji.,,Motoryczny repertuar człowieka, zawierający całą naszą kinetyczną wiedzę zdobywaną w ciągu życia, składa się z motorycznych reprezentacji w mózgu (ang. motor representation), inaczej mówiąc, reprezentacji działania (ang. action representation)"8. Właśnie te neuronalne reprezentacje działania oraz podstawowe, automatyczne reakcje naszego mózgu na ruch - wykonywany czy obserwowany - badane są przez neurokognitywistów. Taniec zarówno choreograficzny, jak i improwizowany ma w tej perspektywie wymiar przede wszystkim umysłowy, ponieważ, jak wynika z badań, poruszając się, człowiek w sposób nieuświadomiony kieruje się mentalnymi reprezentacjami działania. Innymi słowy, zanim wykonamy jakiś ruch, w naszym mózgu pojawia się jego gotowy neuronalny obraz. Teza ta w sposób oczywisty kłóci się z prezentowanymi wcześniej wnioskami wynikającymi z ujęcia enaktywistycznego. O ile z badań inspirowanych fenomenologią i psychologią środowiskową wynika, że człowiek nie tworzy mentalnych reprezentacji danych fragmentów świata, tylko doświadcza go bezpośrednio poprzez poruszające się ciało, o tyle neurobadania mówią, że nie jesteśmy w stanie wyjść poza obrazowy model świata. Jest to zasadnicza, nierozwiązana w pracy sprzeczność, mająca ważne znaczenie dla rozumienia mechanizmów funkcjonowania organizmu ludzkiego oraz poznania. Eksperymenty neurokognitywistyczne mają także pewne ograniczenia dotyczące materiału badawczego wynikające z konieczności unieruchomienia tancerzy i badania aktywności mózgu w odpowiedzi na stymulację motoryczną generowaną przez oprogramowanie komputerowe. A zatem wciąż niewiele wiemy na temat pracy neuronów lustrzanych ${ }^{9}$ w mózgu człowieka rzeczywiście znajdującego się w ruchu. Niemniej, co ważne, taniec funkcjonuje w tej

8 S. Frydrysiak Taniec w sprzężeniu nauki technologii, s. 152.

9 Sieci neuronowych, które aktywizują się zarówno w momencie wykonywania przez podmiot pewnej czynności, jak i w momencie obserwowania tegoż działania. Zob. J. Bauer Empatia. Co potrafiq lustrzane neurony, przeł. M. Guzowska-Dąbrowska, PWN, Warszawa 2008. 
perspektywie nie tylko jako przedmiot badania, ale i narzędzie, wywołując rezonans także w świecie nauk przyrodniczych. Z kolei zainspirowani przez naukowców tancerze coraz częściej podejmują eksperymenty z dziedziny artscience (tworzenie choreografii za pomocą programów komputerowych, pobudzenie ciał wykonawców impulsami generowanymi przez urządzenia elektroniczne, komponowanie utworów za pomocą cyfrowej interakcji z widzami itd.). Ten swoisty mariaż tańca i technologii został opisany w trzecim rozdziale książki na przykładach prac między innymi Merca Cunninghama, Billa T. Jonesa, Kirka Woolforda, Yacova Sharira, Wayne'a McGregora i Williama Forsythe'a.

Należy podkreślić, że w swoich badaniach Sandra Frydrysiak stosuje bardzo specyficzną i moim zdaniem ograniczającą definicję tańca. Pojęcie to wywodzi przede wszystkim z działań twórców postmodern dance (między innymi z improwizacji kontaktowej), które uważa za okres decydujący w dziejach rozwoju sztuki tańca oraz mający wpływ na refleksję naukową. W jej ujęciu taniec to "praktyki artystyczne wykorzystujące ciało i ruch, podbudowane teoretycznie, konceptualizowane przez samych artystów"10. Taniec odgrywa tu rolę soczewki, przez którą badaczka obserwuje „rozwój percepcyjnych zdolności człowieka w kontekście techno-nauko-kultury"11. Poza zainteresowaniem autorki pozostają więc spontaniczne ekspresje ciała oraz gesty istniejące jako jednorazowe wyrazy uczuć, niekonceptualizowane, ale niezwykle ważne zarówno w przestrzeni społecznej, jak i w życiu poszczególnych osób. A przecież badania neurokognitywistyczne pozwalają mówić o tym, że każde doświadczenie motoryczne tworzy wewnętrzne schematy ruchu i rozwija percepcyjne zdolności człowieka. Nie można też zaczynać historii wzajemnych inspiracji pomiędzy nauką a tańcem od połowy XX wieku i działań artystów Judson Dance Theatre. Oto kilka wcześniejszych przykładów: Loïe Fuller w poszukiwaniu scenicznych efektów świetlnych współpracowała z Pierre'em i Marią Curie, Isadora Duncan odwoływała się do filozofii Fryderyka Nietzschego oraz teorii ewolucji Karola Darwina, a wpływ psychologii i fizjologii na prace Wsiewołoda Meyerholda jest powszechnie znany ${ }^{12}$. Zresztą, jak pisze Jean-Marie Pradier, już od czasów starożytnych sztuka teatru była traktowana jako jedna z dróg poznania,

10 S. Frydrysiak Taniec w sprzężeniu nauk i technologii, s. 9.

11 Tamże.

12 Zob. J.-M. Pradier Ciało widowiskowe. Etnoscenologia sztuk widowiskowych, przeł. K. Bierwiaczonek, PWN, Warszawa 2012. 
a historia teatru jest „niemożliwa do oddzielenia od historii spojrzenia, nauk o życiu i psychologii"13. Nawiasem mówiąc, sami twórcy postmodern dance po okresie eksperymentów z ruchem zwrócili się w stronę teatralnej widowiskowości i wirtuozerii ${ }^{14}$, a historia i samo pojęcie tańca, podobnie jak ogólnie rozumianych praktyk artystycznych w wieku XX, nie ograniczają się do eksperymentów z obszaru artscience.

Nie ulega wątpliwości, że wnioski o poznawczym, usytuowanym cieleśnie wymiarze sztuki tańca poparte „twardymi” (naukowymi, jak podkreśla czasami badaczka) argumentami mają duże znaczenie dla różnych dyscyplin wiedzy: biologii ewolucyjnej, badań nad sztuczną inteligencją, neuronauki, ale także filozofii, antropologii kulturowej czy psychologii. Niemniej należałoby zadać pytanie, czy los człowieka sprowadza się jedynie do biologii? Czy pragnienie, wolę, myśl można sprowadzić do neuronu? Jak wtedy wytłumaczyć indywidualne reakcje poszczególnych ludzi na te same bodźce oraz istniejące różnice kulturowe? Co możemy powiedzieć o społeczeństwie, którego członkowie w celu wymiany doświadczeń motorycznych muszą podłączyć się do komputera albo skorzystać z pomocy gogli do rzeczywistości wirtualnej (np. Oculus Rift) ${ }^{15}$ ? Jeżeli wcześniej ciało pojmowane było jako mechanizm sterowany przez niematerialną duszę, teraz ten "mechanizm” wprawiany będzie w ruch przez sieć komputerową. Czy aby w miejsce starej opozycji ciało-rozum nie pojawia się nowa - ciało-mózg czy też ciałokomputer? Obrazowy model świata zdaje się tak zakorzeniony w naszym myśleniu, że nawet „poznanie ucieleśnione” przedstawiamy sobie nie inaczej niż za pomocą metafory lustra (stąd m.in. nazwa neuronów lustrzanych), w którym odbijają się zewnętrzne wobec podmiotu reprezentacje świata. Trzeba zauważyć, że perspektywa neurokognitywistyczna - choć wydaje się atrakcyjna - niezwykle spłyca perspektywę badań nie tylko nad poznaniem, ale i samym tańcem. Jeśli pójdziemy tym tropem, będziemy mieli coraz większą wiedzę o funkcjonowaniu systemu nerwowego oraz motoryce ciała, ale z pewnością nic nie będziemy mogli powiedzieć o sztuce tańca. Metataniec, zakładający oddanie sprawczości w „ręce” nowych technologii, oprócz

Tamże.s. 29.

Zob. S. Banes Terpsychora w tenisówkach. Taniec post-modern, przeł. A. Grabowski, J. Majewska, PWM, Kraków 2013.

Chodzi o projekt The Machine to be Another, w którym użytkowniczkom i użytkownikom oferuje się "zanurzenie w obcy cielesny świat" - swoistą, generowaną technologicznie empatię. Zob. S. Frydrysiak Taniec w sprzężeniu nauk i technologii, s. 347-349. 
oczywistych korzyści terapeutycznych ${ }^{16}$ czy też stwarzania okazji do interakcji tańczącego ciała z komputerem (co włącza sztukę tańca w perspektywę posthumanistyczną) posiada także swoją „,iemną" stronę. Z początku, zwracając uwagę na fizykalność aktu tworzenia i samego bytu tańczącego, neurobadania paradoksalnie prowadzą nas w stronę odcieleśnienia tańca. Wątpliwość dotyczy tego, czy możemy się zgodzić, aby ekspresja cielesna - a właściwie i życie człowieka - zostały sprowadzone do zależnej od technologii interaktywnej biosymulacji. Nie chodzi o odrzucenie zdobyczy neurobiologicznych eksperymentów, ale o większy krytycyzm wobec dominacji perspektywy nauk ścisłych w podejściu do życia.

\section{Taniec jako część politycznej kinesis}

Niezwykle ciekawą perspektywę do badań nad tańcem wprowadza Wojciech Klimczyk. W swojej pracy Wirus mobilizacji. Taniec a kształtowanie sięnowoczesności (1455-1795) prezentuje historię wyłaniania się podmiotu i społeczeństwa nowoczesnego na tle rozwoju idei, a także „kinetycznej wrażliwości danego miejsca i czasu"17. Autor wychodzi z założenia, że kultura jest polem sił popychających ciało w określonym kierunku. Nigdy nie jest ona bezcielesna. Nie można więc według niego mówić o kształtowaniu ciała przez kulturę, tylko o współistnieniu obojga. „Ludzka egzystencja jest zawsze uruchamianiem do, puszczaniem w ruch"18 , czyli doświadczeniem społecznym. Ruch rozumiany jest bardzo szeroko - w postaci fizycznej, ale i społecznej, aksjologicznej, światopoglądowej, estetycznej, uczuciowej. Charakter bycia autor określa mianem "poruszalnego"19 (inspirowanego kategorią „postrzegalnego" Jacques'a Rancière'a) - pola, w którym różne siły walczą o kinetyczny kształt kultury. Taniec jest tu częścią kinesis (porównywanej do Foucaultowskiej episteme), pewnej formy nakładanej przez kulturę na właściwie nieograniczony ludzki potencjał ruchowy oraz wyobraźnię kinetyczną. Ponieważ motoryczne artykulacje jednostek istnieją w ramach kulturowej definicji ruchu i społecznie określanej przestrzeni poruszania, przyglądając się sposobom tańczenia

\footnotetext{
16 Wyniki neurobadań tańca wykorzystuje się m.in. w terapii osób z problemami psychicznymi, jak również z urazami narządów ruchu i układu nerwowego. W. Klimczyk Wirus mobilizacji. Taniec a kształtowanie się nowoczesności (1455-1795), t. 1: Dworskie kroki, Universitas, Kraków 2015, s. 17. Tamże, s. 15. 
oraz formie, jaką przyjmowały widowiska taneczne, wiele można powiedzieć na temat kultury kinetycznej i na odwrót.

Na podstawie charakterystycznych dla epoki renesansu i oświecenia tekstów kulturowych - dzieł literackich i filozoficznych, traktatów tanecznych oraz obrazów - a także bogatej literatury przedmiotu autor rekonstruuje kinetyczny światopogląd wyłaniającego się w nowożytności społeczeństwa mieszczańskiego.Ten okres według Klimczyka cechuje mobilizacja kształtująca wizję człowieka nowoczesnego. Oznacza ona aktywność, postępującą indywidualizację oraz przypisywanie coraz większej sprawczości jednostce. Taniec uwikłany zostaje w procesy polityczne, używany jest jako środek symbolicznego wzmacniania pozycji władców, z których każdy ma własne preferencje kinetyczne.

Nowoczesna kinesis zaczyna się rozwijać w renesansowych Włoszech i przejawia zarówno w sonetach Petrarki, myśli Niccolo Machiavellego, dziełach Sandra Botticellego, Michała Anioła, Leona Battisty Albetiego, jak i w jednym z pierwszych traktów o tańcu De pratica seu arte tripudii Guglielma Ebreo z Pesaro. Z Włoch taneczna moda rozprzestrzenia się na inne kraje Europy. W renesansowej Francji staje się częścią politycznej gry o wpływy i decyzyjność. Jak się okazuje bowiem, wszyscy francuscy monarchowie byli podatni na uroki Terpsychory, a opanowanie standardów pałacowej kinesis było obowiązkowe dla arystokracji. Oprócz tego widowiska taneczne wykorzystywano w kontaktach międzynarodowych w celu ukazania potęgi francuskiej monarchii. Zmienia się także stosunek do tańca - pojawia się tendencja do systematyzacji i porządkowania ruchów, wykluczone zostają spontaniczność i improwizacja, znaczenie zyskują kunszt i techniczna dyscyplina. Jak pisał Thoinot Arbeau, autor traktatu Orchésographie, taniec to przede wszystkim „ćwiczenie mające prowadzić do cielesnej dyscypliny, która jest warunkiem ogólnego rozwoju" ${ }^{20}$. W dobie francuskiego renesansu i klasycyzmu ścierały się ze sobą różne poglądy kinetyczne, ale zarówno u Michela de Montaigne, jak i później u Blaise'a Pascala czy René Descartesa zajdziemy upodobanie do dystynkcji i taneczny konserwatyzm. „Wystudiowana naturalność" - tak w dużym uproszczeniu można by scharakteryzować francuską kinesis. Polityka kinetyczna Francji opierała się na przeświadczeniu, że społeczeństwo buduje się za pomocą systemu rang i dystynkcji wypracowywanych między innymi dzięki umiejętnościom tanecznym. Nieco inaczej kinetyczna rzeczywistość wyglądała w Anglii. Mimo iż i tam taniec był cielesną technologią władzy, to na przełomie XVII i XVIII wieku zaczyna on wyrażać emocje 
zindywidualizowane. Uwarunkowane to było bardziej dynamiczną, podatną na zmiany strukturą społeczną, zwłaszcza wpływami ukształtowanej jeszcze w czasach Tudorów przedsiębiorczej gentry class. Taniec w Anglii „traktowano jako aktywność sytuującą się między badaniem filozoficznym a ćwiczeniem sprawnościowo-zdrowotnym"21. Według Wojciecha Klimczyka angielską kinesis oprócz większej żywiołowości władców ukształtowały aktywistyczne nastawienie do rzeczywistości Francisa Bacona, poglądy filozoficzne Thomasa Hobbesa i Johna Locke'a, dynamika postaci w sztukach Williama Shakespeare'a, niechęć do manieryzmów, pielęgnowanie naturalnego, zgodnego z ludzką anatomią ruchu Johna Weavera, a także ogólne upodobanie do tańców ludowych i pantomimy w duchu tradycji dell'arte.

Ostatecznie dzieło mobilizacji dokonało się w dobie francuskiego oświecenia, którego przedstawiciele byli, jak zauważa autor, anglofilami. W kontekście rozważań nad tańcem na uwagę zasługuje zainteresowanie encyklopedystów fizjologią, przypisywanie ludzkim namiętnościom energii, którą obdarzona jest jednostka, oraz upodobanie do gestu jako kwintesencji emocji. Materialistyczne i sensualistyczne poglądy philosophes, zwłaszcza Étienne'a Bonnota de Codillaca, Anne-Robert-Jacques'a Turgota i Denisa Diderota wpłynęły na jednego z najważniejszych reformatorów baletu Jean-Georges'a Noverre'a, którego Listy o tańcu i baletach stanowią podręcznikowy przykład tekstu oświeceniowego. Taniec w jego ujęciu to natura, która staje się kulturą, a nowa forma przedstawienia - ballet d'action - powinna być ucieleśnieniem dramatu wyciskającego u widza „krwawe łzy”.

Uzbrojeni w podstawowe zasady naszej sztuki, idźmy za głosem własnej duszy - ona nas zdradzić nie może, o ile czuje żywo. Jeżeli w takich momentach unosi się ramię do takiego czy innego gestu, jest on zawsze słuszny i prawidłowo zarysowany, a efekt jego pewny. Namiętności to sprężyny poruszające organizm; jakiekolwiek zrodzą się z nich ruchy, będą na pewno prawdziwe. Należy z tego wnioskować, że jałowe zasady szkolne muszą zniknąć z tańca z akcją, by ustąpić miejsca naturze $\mathrm{e}^{22}$

- pisał choreograf. Umiłowanie „naturalności” zbliżą Noverre’a również do Jean-Jacques'a Rousseau, u którego natura wyraża się w poczuciu

21 W. Klimczyk Wirus mobilizacji. Taniec a kształtowanie się nowoczesności (1455-1795), t. 2: Mieszczańskie gesty, Universitas, Kraków 2015, s. 35. 
autentyczności, niezapośredniczonym „byciu sobą”. Bycie człowiekiem oznacza skrajny indywidualizm, kierowanie się przede wszystkim naturalnymi skłonnościami, a owa wolność utożsamiona zostaje z dobrem i sumieniem. Philosophes stworzyli teoretyczną podbudowę wizji rewolucyjnego indywidualizmu, na uboczu oświecenia czaił się bunt: „Rozemocjonowany podmiot, czerpiący poczucie mocy z przekonania o autotelicznej wartości swoich uczuć, ruszył na podbój świata, wyzbywając się wszelkich w zasadzie hamulców"23. Relacja dialektyczna pomiędzy egoizmem a energią rewolucyjnego tłumu na ostatnich stronach książki wyprowadza na „scenę" nieomylnego indywidualistę Maximiliena de Robespierre’a oraz ekstatyczno-złowrogą, tańczoną w czasach rewolucji karmaniolę.

Klimczyk udowadnia, że mobilizacja społeczeństwa mieszczańskiego odbywała się nie bez udziału tańca, który z kolei nigdy nie istnieje poza kulturą. I chociaż jest to kultura ucieleśniona, ekspresja taneczna w tej perspektywie traci nieco ze swojej wywrotowej żywiołowości, stając się tworem całkowicie sztucznym. Badacz wyraźnie kontynuuje tradycję oświeceniowej wiary w postęp. Bo czym innym jest ukazana przez niego nowoczesna mobilizacja w polu „poruszalnego"? Taniec zostaje tak mocno wpisany w życie idei i ruch myśli politycznej, że chciałoby się z przekorą zapytać o sprawczość indywidualnej ekspresji cielesnej, upomnieć o możliwości wyłamania się z tej struktury, tanecznego oporu wobec władzy dyskursu, jak również o wielkiego nieobecnego tej historii - lud. Czy ciała pospolite, przysadziste i ociężałe, oddające się tańcowi z niezwykłą fizyczną porywczością ${ }^{24}$, nie generowały technik cielesnych będących częścią "poruszalnego" epoki? Te pytania, jak i samo pojęcie kinesis, wiedzy dynamicznej, formującej nasze techniki cielesne, niewątpliwie inspiruje do dalszych poszukiwań.

\section{Taniec jako metoda?}

Omawiane wyżej analizy pokazują coś bardzo ważnego - taniec nie tylko jest przedmiotem badań, ale może być traktowany jako metoda w pozyskiwaniu wiedzy o rzeczywistości. Komunikatywne aspekty ruchów i postaw ciała, performatywne znaczenie gestu są tematem rozważań w teatrologii, antropologii, etnologii, socjologii, kulturoznawstwie, a ostatnio także

23 Tamże.s. 202.

24 Zob. N. Pellegrin Ciało pospólstwa, pospolite zwyczaje ciała, przeł. T. Stróżyński, w: Historia ciała, t. 1: Od renesansu do oświecenia, red. G. Vigarello, słowo/obraz terytoria, Gdańsk 2011, s. 99-148. 
literaturoznawstwie. Preekspresywne techniki cielesne są stałym przedmiotem badań antropologii teatru ${ }^{25}$. Co więc nowego mógłby zaoferować taniec naukom humanistycznym?

Jak słusznie zauważa Daniel Arasse, podmiot nowożytny został „ustrukturowany nie «psychologicznie», lecz «proksemicznie» - autoekspresja i samoświadomość wypracowują się poprzez konstruowanie ciała i gospodarowanie nim w przestrzeni społecznej"26. Innymi słowy, ciało staje się w nowoczesności signifiant wewnętrznych doświadczeń oraz cnót społecznych, ucieleśniających się w znakach fizycznych, gestach i ruchach. Humanistyczny ideał człowieka wyraża się przede wszystkim w wyglądzie - obrazie ciała, istotą szlachetności staje się nie treść, lecz forma. Ten dualizm treści i formy odzwierciedla podział na sfery prywatną i publiczną, jak również ma wpływ na nasze rozumienie relacji z innymi. W tym samym czasie co stosunek do ekspresji cielesnej ukształtowały się sposoby pozyskiwania wiedzy. W zachodniej tradycji poznanie odbywa się poprzez patrzenie z pewnej odległości na analizowany przedmiot - albo właśnie jego obraz. „Myślenie jest przedstawianiem, przedstawiającym stosunkiem do przedstawianego"27 pisał o Medytacjach Kartezjusza Martin Heidegger. A zatem rzeczywistość człowiek poznaje przez analizę tworzonego przez siebie obrazu rzeczywistości. W tym względzie niewiele się zmieniło. „Kto człowieka kiedyś latać nauczy, ten wszystkich rubieży kamienie przesunie [... $]^{\text {"28 }}$ - pisał Nietzsche. I dalej: „Lecz oto ma nauka: kto się kiedyś chce lotu nauczyć, winien się wprzódy nauczyć stać, chodzić, biegać, wdrapywać i tańczyć: - nie wzlatujeż bo się odrazu do lotu!"29. Czy to nie oznacza, że według Nietzschego poznanie powinno odbywać się nie poprzez przedstawianie, ale „w ruchu”? Taniec rzeczywiście zwraca naszą uwagę nie tylko na to, co widoczne - kroki i gesty wykonywane na scenie przez tancerza. Przedmiotem namysłu jest tu przede wszystkim energia ruchu oraz to, jak oddziałuje on na odbiorcę, w tym przypadku - samego badacza. Tekst taneczny „czyta się” cieleśnie,

E. Barba Canoe z papieru. Traktat o Antropologii Teatru, przeł. L. Kolankiewicz, D. Wiergowska-Janke, Instytut im. Jerzego Grotowskiego, Wrocław 2007.

D. Arasse Ciało, wdzięk, wzniosłość, przeł. T. Stróżyński, w: Historia ciała, t. 1, s. 417.

Cyt. za A. Friedberg Wirtualne okno. Od Albertiego do Microsoftu, przeł. A. Rejniak-Majewska, M. Pabiś-Orzeszyna, Oficyna naukowa, Warszawa 2012, s. 181.

F. Nietzsche Tako rzecze Zaratustra, przeł. W. Berent, Wydawnictwo Tenet, Gdynia 1991, s. 228. Tamże. s. 230. 
a więc i analiza zwrócona jest do wewnątrz zanurzonego w dynamicznej rzeczywistości podmiotu. Taki rodzaj badania stanowi propozycję poznania siebie w relacji ze światem, wykraczającego poza oświeceniowy kontemplacyjny model wytwarzania wiedzy. „Myśl” i „zmysł” - wyrazy pokrewne ${ }^{\mathbf{3 0}}$. Nie chodzi jednak o to, by proces myślenia zastąpić związanym z ciałem doznawaniem, lecz o zauważenie zmysłowej składowej myśli, dynamizmu jej „wyłaniania”. Nietzsche przekonywał: „Musimy ustawicznie myśli swe ze swego rodzić cierpienia i po macierzyńsku obdzielać je wszystkiem, co w sobie samych posiadamy z krwi, serca, ognia, rozkoszy, namiętności, męczarni, przeznaczenia, fatalności" ${ }^{31}$. Ruch ciała - i w związku z tym także taniec jest jednym z narzędzi poznania. Człowiek to ten, kto „tańczy”, czyli działa, myśli i czuje jednocześnie.

Nowoczesność zrodziła także inną obsesję - poszukiwanie autentyczności, która w dużej mierze określa zarówno praktyki artystyczne, jak i refleksję naukową. Używając pojęć psychoanalizy Freudowskiej, można by zaryzykować twierdzenie, że jesteśmy neurotykami wypierającymi fakt „naturalnej sztuczności” naszego bytu. Przymus odzyskiwania przez nowoczesny podmiot „istoty rzeczy” oraz późniejszego podważania tejże istotowości przypomina opisaną przez Sigmunda Freuda w Poza zasada przyjemności zabawę dziecka z drewnianą szpulką ${ }^{32}$ ("precz” - „tu”). Oznacza to nic innego, jak nieustanne odtwarzanie traumy utracenia „całościowości” i ponowne wystawianie się na nowożytne rozdarcie pomiędzy autentycznością a sztucznością. Czy taniec nie mógłby brać udziału w leczeniu tej "traumy”? W ostatnich minutach filmu Wima Wendersa poświęconego Pinie Bausch ${ }^{33}$ brzmią jej pożegnalne słowa: „Tańczcie, tańczcie, bez tańca jesteśmy zgubieni". Co miała na myśli choreografka, znawczyni ludzkich dusz? Zdaje się, że nie chodziło jej o znalezienie „naturalnego” ruchu ani jego źródła, lecz po prostu o tańczenie. Czyli cielesną ekspresję, scalającą i kojącą nowoczesne rozdarcie pomiędzy nauką a kulturą, autentycznością a sztucznością, ciałem a duszą.

30 A. Brückner Słownik etymologiczny języka polskiego, Krakowska Spółka Wydawnicza, Kraków 1927 , s. 350.

F. Nietzsche Wiedza radosna ("La gaya scienza”) [1882], przeł. L. Staff, w: Dzieła Fryd. Nietzschego, Nakład Jakóba Mortkowicza, Warszawa 1907, t. 6, s. 6.

33 Pina Bausch - tancerka, choreografka, twórczyni Tanztheater Wuppertal. Komponowała swoje niezwykle poruszające dzieła choreograficzne w wyniku rozmów z wykonawcami. 
Wezwanie Nietzschego, aby zwrócić uwagę na "poruszający wszystkie członki gest taneczny" ${ }^{\prime 34}$, choć w nieco innym kontekście niż sto pięćdziesiąt lat temu, wciąż wydaje się aktualne. Rzecz w tym, by zająć się nie tylko ciałem i jego gestami, lecz również owym „poruszeniem” i jego dynamiką. Teoretycy tańca zauważają, że wrażenia kinestetyczne niekiedy głębiej przenikają do świadomości cielesnej niż dźwiękowe czy wizualne ${ }^{35}$. Gest fizyczny wytwarza szczególne doznanie - przeżycie ruchu, które nie sprowadza się do tego, jak ten ruch wygląda na obrazie czy jest opisywany słowami. Rzeczywisty ruch obejmuje całe nasze ciało i generuje bogate doświadczenia. Nie wyraża uczuć, lecz sam jest uczuciem. Jest przedobrazowy i przedjęzykowy, niejako wspólny dla wszystkich. Taniec nie tylko buduje poczucie sprawczości (agency), ale tworząc wspólną neurobiologiczną przestrzeń semantyczną, stymulując inteligencję kinestetyczną i somatyczną empatię, otwiera perspektywy na otaczającą nas rzeczywistość. Wewnętrzne doświadczenia kinestetyczne stanowią podstawę rozumienia wrażeń kinetycznych (ruch widzialny). Innymi słowy, taniec umożliwia sięgnięcie - bez pomocy nowych technologii - do cielesnej pamięci innego, a jednocześnie dzielenie się własnym doświadczeniem. Wychylony ku przyszłości, „trzyma w ręku” naszą bezpośrednią przeszłość, kształtuje swoistą pamięć materii łączącą nas z wiedzą genetyczną minionych pokoleń. W związku z tym taniec może być pojmowany i badany jako żywe archiwum technik cielesnych.

Ruch stanowi podstawę życia. Rozpoznanie jego dynamiki, energii i kierunku oznacza rozpoznanie procesów występujących w rzeczywistości. „Nasze ciała są morfologiami-w-ruchu, rezonują kognitywnie w świece [... $]^{36}$ - pisze Maxine Sheets-Johnstone. I dalej zauważa, że podstawowe pojęcia ludzkie mają swój początek właśnie w ruchu. „Pojęcia pionowości, ekspansywności, wielkości, słabości, trwałości itd. wywodzą się z podstawowej rzeczywistości ruchu"37. Taniec kształtuje kognitywną i zarazem cielesną wiedzę-umiejętnośćc ${ }^{38}$ dotyczącą nie tylko posługiwania się ciałem, ale i rozpoznawania

34 F. Nietzsche Narodziny tragedii albo Grecy i pesymizm, przeł. B. Baran, „Aletheia”, Warszawa 2009, s. 50.

35 Л.Д. Блок Классический танец. История и современность, «Искусство», Москва 1987, S. 255.

36 M. Sheets-Johnstone, Ruch - podstawa realności świata, przeł. K. Zieliński, w: Strategie choreograficzne.s. 56 .

37 Tamże.s. 57.

38 Zob. G. Ryle, Knwing How and Knowing That, "Proceedings of the Aristotelian Society, New Series", Vol. 46 (1945-14), s. 1-16. 
jakości ruchowych. Zmysł kinestetyczny, tak zwane czucie głębokie, nie tylko odpowiada za samoregulację ruchów i interakcję ze światem, ale jest rodzajem fizjologicznego radaru, dzięki któremu odczuwamy impulsy i intencje innych, reagujemy, wyprzedzając naszą świadomość i myśli. To wrażenia kinestetyczne stanowią substancję każdego spektaklu, obrazu, utworu literackiego. Nie przez przypadek mówimy, że nas „poruszają”. Tańczenie wpływa na sensomotoryczne kompetencje podmiotów poznających, uruchamia wyobraźnię kinestetyczną, wyraża człowieka w jego psychofizycznej integralności, zwracając uwagę na „całościowość" doświadczania świata. Wejście - dosłowne i w przenośni - w taniec i „wsłuchiwanie się" we własne doznania nie oznacza powrotu do antropocentryzmu, tylko „dostrajanie się" do świata, kognitywne, afektywne i kinetyczne zharmonizowanie z innymi działającymi w nim aktorami.

\section{Abstract}

\section{Anastasia Nabokina}

JAGIELLONIAN UNIVERSITY (CRACOW)

Why Dance?

The article attempts to define the role of dance in cognition. Nabokina considers neurocognitive and cultural studies perspectives in the study of dance. Choosing as a starting point the metaphor of dance as used by Nietzsche, she proposes to look at dance as dynamic cognition, allowing the subject to harmonise with the world, other actors in it, and the recognition of social processes.

\section{Keywords}

dance, kinesthesia, movement, cognition, Nietzsche 